\title{
In Search of the Epiphany of Homework Assignments: A Model of Evaluating Local Schools' Homework Practices
}

\author{
Dr. Julie Saam*, Dr. Taekhil Jeong \\ School of Education, Indiana University Kokomo \\ *Corresponding Author: jsaam@iuk.edu
}

Copyright (C) 2013 Horizon Research Publishing All rights reserved.

\begin{abstract}
Some parents and students perceived demanding homework assignments as a frequent source of grievance, particularly for those high performing students who want spare time for independent study and cultivation of talents through extracurricular activities. Teachers tended to perceive homework assignments as a meaningful extension of instruction time and a media of communication between school and home. Cognizant of the possible conflicts about homework practices between school and home, the current study investigated homework issues from the students' and their parents' perspective while maintaining the integrity and information provided by the teachers of those students. The overarching goal of the current study was to establish a conceptual and applicable model for evaluating homework practices in local schools. Data collected included student and parent surveys, teacher homework philosophies, sample homework assignments, and homework hallway charts. The survey results were analyzed inductively and six key issues were identified pertinent to homework assignments in a well performing middle school in a Mid-western state in the United States of America. The six prominent factors identified include: grade-level homework coordination, positive perception about homework, homework as academically engaged time, motivation of doing homework, uniqueness of math homework, and ability-matching of homework. Some implications for parents and educators were articulated.
\end{abstract}

Keywords Homework Assignment, Academic Performance, Extra-Curricular Activity, Grade (School) Level Coordination

\section{In Search of the Epiphany of Homework Assignments: A Model of Evaluating Local Schools' Homework Practices}

The American public attitude toward homework during the last several decades can best be summarized as being bifurcated or vacillated between supports and oppositions.
Cooper (2007) defined homework as "the tasks assigned to students by school teachers that are intended to be carried out during non-school hours" (p. 4). On the one hand, many research results claimed that homework plays a major role in students' academic achievement. For example, the average student doing homework had a higher chapter or unit test score than those of $73 \%$ of the students who do not do homework regularly (Canadian Council on Learning, 2009; Cooper, Robinson, \& Patall, 2006; District Administration, 2004 ). On the other hand, some students and parents felt severe frictions between the externally imposed homework assignments and their internally motivated spontaneous extracurricular activity needs (Bennett \& Kalish, 2006; Marsh, 1992; Vatterott, 2009). Encountering some conflicting evidences such as doing homework does not positively correlate with the standardized test score (Begley, 1998; Buell, 2006; Kohn, 2006; Kralovec \& Buell, 2000; Solomon, Warin, \& Lewis, 2002), some parents became even disgruntled with their children's homework burdens. Thereafter, the homework controversies became one of the most frequently found sources of grievance and abrasion between parents and schools. Furthermore, probably as a reflection of those general attitudes or the social ethos of the times, even research results had not been conclusive with the homework efficacy issues (Gill \& Schollsman, 2004; Hong \& Milgram, 2000; Marzano \& Pickering, 2007; Trautwein, Schnyder, Niggli, Neumann, \& Lüdtke, 2009).

The influences of homework entailed complex issues because typical homework assignments are given at school but completed in the home, involving every imaginable stakeholder such as educators, students, parents, and administrators. As expected, a long list of positive consequences of homework had been suggested. For example, proponents of homework argued that doing homework increases the time students spend on academic tasks, and students' academically engaged time was the most significant, immediate, and direct contributor to the students' performances (Cooper, et al., 2006; Epstein \& Van Voorhis, 2001; Hoover-Dempsey et al., 2001; Warton, 2001; ). Almost as equally convincing, however, opponents of homework argued negative influences of homework. For example, homework saturated students blocking them from 
academic pursuit, which in turn caused psychological fatigue, deprived students of access to extracurricular activities, leisure times, and community involvements. This saturation referring to the overexposure to academic tasks stifled spontaneous and intrinsic motivation to learn (Cooper, Lindsay, \& Nye, 2000; Cooper, et al., 2006; Coutts, 2004; Vatterott, 2009 ). Cognizant of the complicated nature of homework issues, recent research proposed that the prescription of homework practice should be calibrated according to the idiosyncratic needs of local school communities (Bailey, 2006; Vatterott, 2009). Fine tuning with such conceptualization of homework, the current study of examining prominent factors of effective homework prescriptions and practices was conducted with the view to establish an evaluative protocol for the local school level.

\section{Research Methods}

In order to understand the complicated issues of homework, we chose a mixed research design that included a descriptive survey as well as qualitative analysis of narrative data. Although the descriptive survey gave us our demographics and parameters providing the underpinnings to our research question, we chose to focus primarily on the qualitative analysis because the qualitative data shed important insights. Jovannovic (2011) stated that "there are plausible academic as well as social indicators that qualitative research has become an indispensable part of the methodological repertoire of the social sciences" (p. 1). Litchman (2013) stated that "the purpose of qualitative research is to describe, understand, and interpret human phenomenon, human interaction, or human discourse" ( $\mathrm{p}$. 17), where phenomena referred to lived experiences of humans, and we thought the purpose of the current study was well suited for such a research paradigm. In short, we wanted "to know the story behind the number" about the homework prescriptions and practices (Mayon, 2009, p. 10). The purpose of the current study was to establish a conceptual and applicable model through which educators can approach complicated homework issues within a local idiosyncratic school level, using a more comprehensive and naturalistic way to gain ground on which we can process, analyze, and evaluate the effectiveness of homework practices. With this purpose guiding our research design, the following research question was formulated for the current inquiry: What factors are prominent in successful prescription and practice of homework assignments?

\subsection{Selection of Participants}

Colleges and university were often conceptualized as the hub of knowledge productions and scholastic services. One of the authors have been served adjacent twelve local school districts in the capacities of professional development, curriculum review, and consultation as a prominent university professor in the regional campus of the state's flagship university for about a decade. Recently, a local principal from the Mid-west school district requested the authors to evaluate the middle school's overall practices of homework, particularly its efficacy and adequacy. The middle school includes grades 6, 7, and 8 and each grade has two interdisciplinary team organizations consisting of the core subject area teachers (Science, Language Arts, Social Studies and Mathematics). The school had been continuously successful in its academic performance over the past decade. For example, the school continuously made Adequate Yearly Progress (AYP) since the NCLB (No Child Left Behind) Act was put into effect in 2001. Moreover, the students' academic performance measured by the ISTEP (Indiana Statewide Testing for Educational Progress) passing rate from 2000 to 2011 indicated that the students had consistently outperformed the State average significantly without exception (Indiana Department of Education, 2012). The local school of the current study was nested in one of the ten states that had been selected to receive NCLB waivers for its continuous excellent academic performance. The principal was a strong homework advocate, maintained a conviction that homework practices of the school had positively impacted the academic performance of the students.

\subsection{Data Collection}

Initially, a survey was conducted for the entire middle school student population and their parents $(n=584)$ and other homework information was gathered from the middle school teachers $(n=34)$. At this stage, the students and their parents were asked to complete a survey questionnaire that consisted of 13 questions (e.g., see Appendix A, the parent and student surveys were identical questions; however, word usage was altered where deemed appropriate to each respective audience). The parent surveys were sent home to the parents via their child along with the Student Consent Form. The Student Consent Forms and completed surveys were returned to the school via the parents' child. Classroom teachers distributed the student survey to students with signed consent. We received a total of $339(58 \%)$ parent surveys and consent forms and administered 319 (55\%) student surveys. Other data collected included: 26 (76\% of teachers) homework philosophy statements; 46 (68\% of total number of homework assignments that require more than 45 minutes in completion) examples of homework assignments; and $6(100 \%$; 2 charts per grade) digital pictures of the homework hallway charts. Also, the school's student demographic information was collected through an Internet search, and the results included: White $88 \%$, Black $4 \%$, Hispanic 2\%, Asian 2\%, Multiracial 5\%; among those students, $78 \%$ paid lunch, 3\% reduced lunch, and 19\% free lunch (Indiana Department of Education, 2012).

\subsection{Data Coding and Analysis}

Because we were interested in the story of the participants and willing to identify the units of information that 
contributed to the themes of the phenomena (Vaughn, Schumm, \& Sinagub, 1996), we used the inductive analysis procedures to analyze and interpret the data. The inductive analysis procedures involved with managing data through coding, categorizing into themes, and determining relationships among the themes (Huberman \& Miles, 1994; Litchman, 2013), whereby determining relationships among the themes referred to finding the manifested trends, patterns, and consistencies among the emerged significant factors. The collected data set, particularly the participant teachers' homework philosophy statements, the homework assignments, and the homework hallway charts were coded and analyzed according to the coding process proposed by Bogdan and Biklen (1998). In the first phase of analysis, we organized all qualitative data by categories of phenomena and for relationships among those categories. Codes were organized with phrases that identified similar patterns, themes, recurring ideas or relationships or differences between and among segments of data. LeCompte (2000) stated that this process of coding the data into epiphanic categories enables researchers to manage and reconstruct meaningful components. The second phase of data analysis involved investigating the identified categories through a display of diagrams of the codes. Coffey \& Atkinson (1996) stated that this strategy facilitated researchers to break up the data in analytically meaningful manners while maintaining a holistic perspective. The third phase of analysis involved collapsing two or more meaningful categories, patterns, and consistencies into a broader thematic unit. Through this process, we were able to establish generalizations that account for the consistencies in the data.

\section{Results}

Harris Cooper (2001 \& 2007) in The Battle over Homework described seven distinctions of homework assignments: Amount, purpose, skill area used, degree of individualization, student choice, completion deadlines, and social context. The homework model proposed that those seven categories were the most critical ones that determined what a homework assignment should contain and how it should be carried out (Coopers, $2001 \& 2007$ ). The results of an analysis of the homework assignments regarding six of these distinctions were located in Table 1. The Amount distinction which referred to frequency of assignments and length of assignments was not analyzed due to the data being a sample of two assignments in a given week and not an exhausted compilation of a year's worth of assignments. The analysis of the homework hallway chart data spoke to the Amount distinction and would follow in this results section.

Since inadequate numbers of homework assignments were collected from the teachers to analyze the data regarding the Cooper's (1989 \& 2007) Amount theme, we analyzed the Homework Hallway Chart data. The following themes spoke to the Amount category and also lead us to an understanding of the coordination efforts of the teachers in regards to homework. The Homework Hallway Chart data also revealed differences between the six grade prescription and practices regarding homework and the rest of the middle school, $7^{\text {th }}$ and $8^{\text {th }}$ grades.

-Very few teachers assign homework on Friday

-Of the four core subjects; language arts, mathematics, social studies, and science, there was never a day that all four subjects assigned homework

- Mathematics homework was assigned daily unless a mathematics quiz or test was scheduled

- Most assignments in Grade 6 were due the following day

- Most assignments in Grade 7 and 8 were not due the following day

- As the grade level increases, so did the complexity of assignments

- As the grade level increases, so did the completion deadline. More long-term projects were assigned in grade 7 and 8 .

When teachers' homework philosophies were analyzed, a synergy was observed between the prescriptive pedagogical theories of homework assignments and the skillful applications of homework practices. The homework practices were synergistic in that the more a teacher was involved, invested, and reflective in homework practices, the teacher was more likely to provide meticulous feedback, individualized explanation as to how to improve students' homework performance, and even meaningful alternatives to the routine homework assignments. Therefore, students would be even more likely to benefit by actually doing the prescribed homework when the teacher authentically valued the worthiness of homework practices as a meaningful extension of teaching activities. As with the homework assignments and the homework hallway chart data, teacher coordination efforts were apparent and also discovered was an awareness of the length of assignments in relation to developmental levels. Five themes emerged from the analysis of teachers' homework philosophy statements.

- Homework is necessary, "Homework is an essential part of a child's education. It promotes critical life skills such as self-discipline, time management, and sense of personal responsibility."

-Providing class time to begin homework is essential, "This way a student has me handy if they run into problems getting started. I encourage them to scan their assignment to see if they anticipate difficulties they may encounter on some of the later problems on each set."

- Coordination with other teachers is essential, "I like the fact that I can see what the other teachers are up to now by having the assignment boards in the hallway."

- Teachers' awareness of length of homework is essential, "I will continue to use my best judgment in assigning work that meets the individual needs of the students and an appropriate amount of homework."

-Homework provides feedback for students and teachers, "It [homework] should not be long, rote work, rather a simple and short gauge of the student's mastery of the lesson's skills." 
The teachers described homework as "essential, vital, integral, and necessary" to the success of their students. They viewed homework as an extension of classroom instruction. Most importantly, the teachers used homework to provide feedback to students and back to themselves in regards to student knowledge, retaining knowledge, and mastery of skills and concepts.

Teachers realized that for homework to be an essential component to student learning at least three themes needed to be at the forefront: coordination with teachers, awareness of length, and providing class time. Therefore, their philosophies indicated that coordination of homework was just as important as coordination of large assignments, tests, and long-term projects. Coordinating the amount of homework given by each teacher in a team and the length of estimated time needed to complete the homework assignments increased the amount of success middle school students have with completion of homework. These teachers expressed the understanding that homework needed to be purposeful and that lots of homework did not equate to increased learning and may also be counter-productive. Length of homework should be based upon the purpose of the homework and the development of the students. The last essential component involved allowing students class time to begin homework assignments. The teachers indicated that allowing students to begin homework gave teachers a chance to monitor understanding, give assistance, and scan for difficulties. Class time was also given for longer, larger assignments so that students were allowed to work individually and in groups.

Finally, teachers expressed that homework came in many forms and could be used for a variety of purposes including: skill application, reinforce foundations, review, new material introduction, independent practice, integrate skills and enrichment. Homework could also serve as a model for self-discipline, time management, and personal responsibility.

Results from the analysis of the student and parent survey data revealed specific information regarding students and parents views of homework. Following are a few of the highlights:

$\bullet 70+\%$ of students finish all assigned homework five nights a week

- Grades and self-satisfaction are the primary motivators of doing homework

-Parents or no one help the students with their homework; i.e., siblings or friends are rarely of assistance

-Most students perceive homework to be very to somewhat important

\section{Discussions and Implications}

The research question of the current study was to identify prominent significant factors that affect effective homework prescriptions and practices. Contextualizing the emerged themes and findings of the current study into the existing educational research literature, the following implications and tentative conclusions were conceived.

1.The school's team-level homework coordination using the hallway homework chart had been very effective. It was evident in the findings that no student ever received homework in all four core subjects on a given night and very few teachers assigned homework on Friday. Given the importance of homework, it is surprising to learn how few schools or school districts actually had homework policies or systematic homework coordination; i.e., only $35 \%$ of school districts had written homework policies (Cooper, 2007; Roderique, Polloway, Cumblad, \& Bursuck, 1994). Homework assignments need to be coordinated at least at team-level, ideally at grade and school level because each subject teacher does not know the full scope of students' homework assignments on each night. It should be remembered that every student takes part in four core curriculum at any given school day simultaneously. Therefore, it is essential for schools to have a homework policy established and to have systematic school-wide homework coordination in place.

2. Most students of the school perceived the homework to be very to somewhat important as well as the teachers deemed it necessary. Also, the teachers of the school have designated a few minutes (usually 3-7 minutes toward the end of the class time) during class time to begin the assigned homework. Finally, the school had outperformed the state average on ISTEP test consistently over the ten consecutive years. Overall, the school placed a high (if not the highest) priority in academic learning. The school ethos and learning environment impacted the performance of the students because the mentality of students might be influenced by the overarching atmosphere of the school (Savage, Savage, \& Armstrong, 2006). Promoting academic excellence through having an academic achiever award ceremony or a distinguished alumni night might spell out the importance of academic achievement. The students at this school appeared to be absorbed into the school ethos that academic performance matters.

3. More than $70 \%$ of the students finished all assigned homework five nights a week, and about $30 \%$ or less students had difficulties with completing homework on time. The issues of homework assignments bifurcated the performance of students. The doers of homework tended to perform well with their academic subjects while the students who didn't do their homework tended to perform behind their grade level (Coopers, 2007). Therefore, the academic performance gap tended to become even more widened from the juncture point of homework habits as the academic year went on (Marsh, 1992). One implication of the finding was that some homework assignments might have been too difficult for some low achievers (students not doing homework); i.e., they could not complete the homework assignments independently without parental help even when they wanted to do their homework. Teachers should not issue a homework assignment that requires a fully functioning 
independent skill for the low achievers, the threshold of low achiever for the school appeared to be the bottom $20-30 \%$. Cooper (2007) offered a sobering caution, "students who fall below a minimum competence in a skill area may not benefit from homework at all" (p. 36). Considering the social context and skill area utilized, it is recommended for the teachers to individualize homework assignments for low-achieving students or at least build-in some task options in the homework, as opposed to giving out independent homework assignments to all students (Margolis, 2005). We found that about $87 \%$ of the total homework assignments of the school required proficient and independent academic skills to complete homework assignments appropriately and adequately. It is disheartening to learn that almost every high school dropout points out their inability to complete homework assignments as being the catalyst of his/her decision to quit school for good (Bailey, 2006; Kralovec \& Buell, 2000; Olson, 2008; Rothstein, 2004).

4.Grades and self-satisfaction were the primary motivators of doing homework, and the majority of the students completed all the homework requirements regularly. However, this evidence did not lead us to the conclusion that the school was concern-proof. According to the research of Marsh (1992), dedicated parents tended to be more concerned about the time constraints in completing homework assignments on time because their children had participated in various extracurricular activities. It was interesting to see that complaints and concerns regarding homework were more likely initiated by caring parents, not self-indulged individuals. Homework policy and school level homework coordination were essential for schools and school districts, even those school systems that housed well performing students and cohesive parents.

5.Mathematics homework had been assigned daily unless a math quiz or test was scheduled for the school. The current daily math homework practice of the school found some research support; i.e., "the average correlation between time on homework and math achievement was statistically stronger than that involving reading," (Coopers, 2007, p. 29) or any other school subjects (Trautwein, Koller, Schmitz, \& Baumert, 2002). This finding appeared to speak to the uniqueness of Mathematics curriculum. Mathematics could be taught primarily in two ways; i.e., conceptually or procedurally with the hope that the other will illuminate eventually since they are complimentary (Goos, Dole, Makar, 2007; Remillard \& Bryans, 2004; Reys, Lindquist, Lambdin, \& Smith, 2009). Teaching mathematics procedurally referred to a traditional, rule-based, step-by-step, and skill mastery approach of facilitating students' learning, as opposed to conceptual learning. Constructivist approach of learning Mathematics (e.g. conceptual learning) included assuring the illumination of why one should follow the given rule and step-by-step algorithm, promoting students' communication skills and problem solving capacities, and enabling students to experience the actual processes of mathematical thinking (e.g., conjecture, generalization, proof, refutation) (Australian Education Council, 1991; Frid, 2000; Goos, et al., 2007). Unless having a precedent understanding about why, it was hard or demoralizing to carry out all the steps of solving a math problem purely depending on a step-by-step rote memorization, particularly when it involved abstract and complicated concepts, which was most often found in solving math problems. Stacey (2003) criticized the procedural approach as a syndrome of shallow teaching, where students experienced a diet of excessive repetition, problems of low complexities and variations, and mathematical concepts of little applicability with very few opportunities for mathematical reasoning. The retention of procedural knowledge without conceptual understanding necessitated continuous practices (i.e., daily homework) because the students would not be able to perform to the standard without daily reinforcements of the retention (Hyde, Else-Quest, Alibali, Knuth, \& Romberg, 2006; Lingard et al., 2001). Requiring daily math homework assignment might imply that the school's teaching of mathematics probably depended too much on procedural algorithms without conceptual understanding. Conceptual learning of mathematics should be balanced with procedural learning.

6.Most assignments in Grade 6 were due on the following day (i.e., immediate short-term), as compared to Grade 7 and 8 which were not due on the following day (i.e., comparatively long-term). Also, as grade level increased, so did the complexity of assignments. Research findings well supported the current homework practices of the school (Cooper et al., 2006). The magnitude of correlation differences between time spent on homework and academic performance manifested a statistical significance according to the different grade levels of students (Vatterott, 2009). According to Cooper (2007), the average correlation between time spent on homework and achievement was substantial for secondary students (Grades 7-12), as opposed to its effect was hovering around zero for elementary students. There were several plausible explanations as to why the homework-achievement relationship differed at various grade levels; however, those various explanations were categorized into two trends in the current discussion. First, according to the library of knowledge proposed by developmental psychologists, children demonstrated a qualitatively different cognitive ability depending on their maturity (i.e., developmental stages). The meta-cognitive skills of elementary students were not commensurate with those of secondary school students; i.e., while secondary students may well have benefitted from doing homework, elementary student were not developmentally ready to reap any benefits from doing homework due to their limited attention span, learning strategy, ability to regulate their study habits, and time management skill, etc. Second, the attitudes about homework were noticeably different from teachers of elementary to that of secondary schools. Coopers (2007) found that one of the most prominent reasons of assigning homework in elementary school was 
communicating with parents as to what they were doing at school and helping the students to learn self-discipline and time management skills, while secondary school teachers used the homework opportunity to extend, apply, and integrate the cognitive knowledge that had been taught during class lessons. It was obvious that the self-discipline and time management skills were almost never to be tested within standardized tests, as compared to the cognitive skills of comprehending, applying, and synthesizing, etc.. Therefore, the homework practice of the current study school seemed to be appropriate and adequate overall, particularly considering the students' developmental level and afore-referenced research findings.

\section{Conclusion}

Examining prominent factors of effective homework prescriptions and practices of a well-performing middle school in the mid-western region of the United States, gave us a glimpse into at least one variable among many when one was trying to fully understand the complexities of a school system. This study offered the prescription and practices used by teachers in a middle school that proved to be successful on the academic side of cognitive student performance as well as on the affective side of collegiality among teachers, parents and students. The current study was driven by the goal of developing a conceptual protocol and applicable model of evaluating homework practices for its adequacy and efficacy. Data collected included student and parent surveys, teacher homework philosophies, sample homework assignments, and homework hallway charts. The six prominent contributing factors of adequate and effective homework practices were identified: grade-level homework coordination, positive perception about homework, homework as academically engaged time, motivation of doing homework, uniqueness of math homework, and ability-matching of homework. Major implications of each finding were discussed and deliberated in the light of existing homework research findings for its theoretical and practical applicability.

Being open to future replication of the study about homework practice, we acknowledged that there were limitations to current study. The current study was not a typical research study that attempted to explicate the relationship between variables or to measure the magnitude of treatment effects in an impersonal and quantitative scientific way. Rather, the current study was conducted with the goal of developing a new model for evaluating homework practices in a personal, contextualized, and naturalistic way. From the inception of current research, we were more interested in the richness of the information we illuminated from students, parents, teachers, and school administrators than the ability to generalize the current findings into other cases or to test specific hypothesis driven by particular theories of education. For this reason, we did not examine a particular theory nested in homework research literatures. Therefore, the limitation of the current study should not be considered as non-scientific, rather the construct of a different process of qualitative science. Overall, this qualitatively designed study might lead us to a more complete understanding about adequate and effective homework practices, supplementing homework research conducted in traditional quantitative approaches.

\section{Appendix A}

\section{Western Middle School-Western School Corporation \\ Parent Survey \\ HOMEWORK \\ Please circle all appropriate responses concerning your child \\ Grade \\ $\underline{\text { Team }}$ \\ 6 \\ Navigators \\ Liberty \\ Pathfinders \\ 7 \\ 8 \\ Explorers \\ Freedom \\ Incredible Universe}

Please circle the letter of your response

1.How much time on average does your child spend on homework every night?

a. 0 - 30 minutes

b. 30 minutes -1 hour

c. 1 hour $-1 \frac{1}{2}$ hours

d. $1 \frac{1}{2}$ hours -2 hours

e.More than 2 hours

2.At what time of the evening does your child usually begin homework?

a.As soon as he/she arrives home from school

b.After dinner

c.After other activities

d.Just before bedtime

e.Other

(Please

list)

3.Where does your child most often do homework?

a.Kitchen or Dining Room

b.Bedroom

c.Living Room

d.Home Office

e.Car

f.School

g.Other

(Please

list)

4.How many of your child's teachers assign homework every night?

a.5-6

b. $3-4$

c. $1-2$

5.How much time on average does a teacher give your child in class to work on homework?

a.Less than 5 minutes

b. 5 - 10 minutes

c. $10-15$ minutes

d. $15-20$ minutes

e.More than 20 minutes 
6.How many nights per week is your child able to finish all assigned homework?
a.5 nights
b. 4 nights
c. 3 nights
d. 2 nights
e. 1 night
f.0 nights

7.What motivates your child most often to do homework?

a.Self-satisfaction

b.Parental approval

c.Peer competition

d.Discipline line

e.Grades

f.Other

(Please

list)

8. Who usually helps your child at home with homework?

a.Parent

b.Friend

c.Older sibling

d.No one

e.Other

(please

list)

9.How many days a week does your child have PowerTable?

a.0

b. 1

c. 2

d. 3

e. 4

f.5

10.List all WMS extracurricular activities your child is a part of at school. Next to the activity, put how many hours a week your child participates in that activity.

\begin{tabular}{|l|l|}
\hline Activity & Average hours per week \\
\hline & \\
\hline & \\
\hline & \\
\hline & \\
\hline & \\
\hline
\end{tabular}

11. List all activities your child is a part of outside of school (non-school related activities). Next to the activity, put how many hours a week your child participates in that activity.

\begin{tabular}{|l|l|}
\hline Activity & $\begin{array}{c}\text { Average hours } \\
\text { per week }\end{array}$ \\
\hline & \\
\hline & \\
\hline & \\
\hline & \\
\hline & \\
\hline
\end{tabular}

12. What keeps your child from getting homework done at home?

a.Time

b.Atmosphere

c.Lack of Help

d.Other

(Please

13.How important do you believe homework is?

a.Very Important

b.Somewhat Important

c.Not Important

Please place the completed survey in a sealed envelope (provided). Send survey with your child to school to be placed in an appropriate envelope in your child's first period classroom.

Table 1. Adopted from Cooper's comprehensive homework model (2001 \& 2007)

\begin{tabular}{|c|c|c|}
\hline Distinctions & Sub-distinctions & $\begin{array}{l}\% \text { of sample } \\
\text { assignments }\end{array}$ \\
\hline $\begin{array}{l}\text { Amount: Total amount of time spent } \\
\text { on assignments per night or per week }\end{array}$ & $\begin{array}{l}\text { Frequency } \\
\text { Length }\end{array}$ & \\
\hline $\begin{array}{l}\text { Purpose: the reasons the homework } \\
\text { assignments are given }\end{array}$ & $\begin{array}{l}\text { Practice } \\
\text { Preparation } \\
\text { Extension } \\
\text { integration }\end{array}$ & $\begin{array}{r}30 \\
7 \\
26 \\
37\end{array}$ \\
\hline $\begin{array}{l}\text { Skill area used: the homework } \\
\text { assignments emphasize writing, } \\
\text { reading, or retention and memory }\end{array}$ & $\begin{array}{c}\text { Writing } \\
\text { Reading } \\
\text { Memory/Retention }\end{array}$ & $\begin{array}{r}7 \\
65 \\
28\end{array}$ \\
\hline $\begin{array}{l}\text { Degree of individualization: } \\
\text { homework assignments can be } \\
\text { geared to the needs of individual } \\
\text { student or groups of students }\end{array}$ & $\begin{array}{l}\text { Individual student } \\
\text { Groups of students }\end{array}$ & $\begin{array}{r}4 \\
96\end{array}$ \\
\hline $\begin{array}{c}\text { Student choice: homework } \\
\text { assignment can be provided with } \\
\text { students choice in either of the two } \\
\text { options: compulsory with task } \\
\text { options or voluntary }\end{array}$ & $\begin{array}{l}\text { Compulsory } \\
\text { Voluntary }\end{array}$ & $0^{100}$ \\
\hline $\begin{array}{c}\text { Completion deadline: homework } \\
\text { assignments can be either long-term } \\
\text { or short term } \\
\end{array}$ & $\begin{array}{l}\text { Long-term } \\
\text { Short-term }\end{array}$ & $\begin{array}{l}70 \\
30\end{array}$ \\
\hline $\begin{array}{l}\text { Social context: homework } \\
\text { assignments can be geared to student } \\
\text { to work on independently, assisted, } \\
\text { or in a group }\end{array}$ & $\begin{array}{l}\text { Independent } \\
\text { Assisted } \\
\text { Group }\end{array}$ & $\begin{array}{r}87 \\
0 \\
13\end{array}$ \\
\hline
\end{tabular}

\section{REFERENCES}

[1] Australian Education Council. (1991). A National Statement on mathematics for Australian schools. Melbourne: Curriculum Council.

[2] Bailey, L. (2006). Interactive homework: A toll for fostering parent-child interactions and improving learning outcomes for at-risk young children. Early Childhood Education Journal, 34(2), 155-167.

[3] Begley, S. (1998, March 30). Homework doesn't help. Newsweek, p. 50. 
[4] Bennett, S, \& Kalish, N. (2006). The case against homework: How homework is hurting our children and what we can do about it. New York: Crown Publisher.

[5] Bogdan, R.C., \& Bilken, S. K. (1998). Qualitative research for education: An introduction to theory and methods (3rd ed.). Boston, MA: Allyn \& Bacon.

[6] Buell, J. (2006). Closing the book on homework: Enhancing public education and freeing family time. Philadelphia: Temple University Press.

[7] Canadian Council on Learning. (2009, May 4). A systematic review of literature examining the Impact of homework on academic achievement. Retrieved from http://www.ccl-cca.ca/CCL/Newsroom/Releases/20090504H omework.htm

[8] Coffey, A., \& Atkinson, P. (1996). Making sense of qualitative data: Complementary research strategies. Thousand Oaks, CA: Sage.

[9] Cooper, H. (1989). Homework. White Plains, NY: Longman.

[10] Cooper, H. (2001). The battle over homework: Common ground for administrator, teachers, and Parents (2nd ed.). Thousand Oaks, CA: Corwin Press, Inc.

[11] Cooper, H. (2007). The battle over homework: Common ground for administrator, teachers, and parents (3rd ed.). Thousand Oaks, CA: Corwin Press, Inc.

[12] Cooper, H., Lindsay, J. J., \& Nye, B. (2000). Homework in the home: How student, family, and parenting style differences relate to the homework process. Contemporary Educational Psychology, 25, 464-487.

[13] Cooper, H., Robinson, J. C., \& Patall, E. A. (2006). Does homework improve academic achievement? A synthesis of research, 1987-2003. Review of Educational Research, 76 (1), $1-62$.

[14] Coutts, P. M. (2004). Meaning of homework and implication for practice. Theory into Practice, 43, 182-188.

[15] District Administration. (2004, February). Taking a closer look at homework. Retrieved from: http://www.districtadministration.com/viewarticle.aspx?artic leid $=476$

[16] Epstein, J. L., \& Van Voorhis, F. L. (2001). More than minutes: Teachers role in designing homework. Educational Psychologists, 36, 181-193.

[17] Frid, S. (2000). Constructivism and reflective practice in practice4: Challenges and dilemmas of a mathematics educator. Mathematic Teacher Education and Development, 2, 17-33.

[18] Gill, B. P., \& Schollsman, S. L. (2004). Villain or savior? The American discourse on homework, 1850-2003. Theory into Practice, 43 (3), 174-181.

[19] Goos, M, Dole, S, Makar, K. (2007). Supporting an investigative approach to teaching secondary mathematics: A professional development model. Mathematics: Essential Research, Essential Practice, 1, 325-334.

[20] Hong, E., \& Milgram, R. M. (2000). Motivation and learning preference. Westport, Connecticut: Bergin \& Gravey.

[21] Hoover-Dempsey, K.V., Battiato, A.C., Walker, J. M.T.,
Reed, R. P., DeJong, J.M., \& Jones, K.P. (2001). Parental involvement in homework. Educational Psychologists, 36, 195-209.

[22] Huberman, A.M., \& Miles, M.B. (1994). Data management and analysis methods. In N. K. Denzin \& Y. S. Lincoln (Eds.), The handbook of qualitative research (pp. 428-444). Thousand Oaks, CA: Sage.

[23] Hyde, J. S., Else-Quest, N. M., Alibali, M. W., Knuth, E., \& Romberg, T. (2006). Mathematics in the home: Homework practices and mother-child interactions doing mathematics.

[24] Journal of Mathematical Behavior, 25 (2006), 136-152.Indiana Department of Education (2012). School data: School snapshot of Western Middle School. Retrieved from:

http://mustang.doe.state.in.us/SEARCH/snapshot.cfm?schl= 2922Jovannovic, G. (2011). Toward the social history of qualitative research. History of the Human Sciences, 24(2), $1-27$.

[25] Kohn, A. (2006). The homework myth: Why our kids get too much of a bad thing. Cambridge, MA: Da Capo Press.

[26] Kralovec, E., \& Buell, J. (2000). The end of Homework: How homework disrupts families, overburdening children, and limit learning. Boston, Massachusetts: Beacon Press.

[27] LeComte, M.D. (2000). Analyzing qualitative data. Theory into practice, $39,146-154$.

[28] Lingard, R., Ladwig, J., Mills, M., Bahr, M., Chant, D., Warry, M., Hayes, D., Gore, J., Like, A. (2001). The Queensland School Reform Longitudinal Study. Brisbane: Education Queensland.

[29] Litchman, M. (2013). Qualitative research in education: A user's guide (3rd ed.). Thousand Oaks, CA: Sage.

[30] Margolis, H. (2005). Resolving struggling learners' homework difficulties: Working with elementary school learners and parents. Preventing School Failure, 50(1), 5-12.

[31] Marsh, H. W. (1992). Extracurricular activities: Beneficial extension of traditional curriculum or subversion of academic goals? Journal of Educational Psychology, 84, 553-562.

[32] Marzano, R. J., \& Pickering, D. J. (2007, March). The case for and against homework. Educational Leadership, 64(6), 74-79.

[33] Mayan, M. (2009). Essentials of qualitative inquiry. Walnut Creek, CA: Left Coast press.

[34] Olson, K. (2008). The wounded student. Educational Leadership, 65(6), 46-49.

[35] Patton, M. Q. (2002). Qualitative education and research methods (3rd ed.). Thousand Oak, CA: Sage.

[36] Remillard, J., \& Bryans, M. (2004). Teachers' orientations toward mathematics curriculum materials: Implications for teacher learning. Journal for Research in Math4ematics Education, 35, 352-388.

[37] Reys, R. E., Lindquist, M. M., Lambdin, D. V., \& Smith, N. L. (2009). Helping children learn Mathematics (9th ed.). Hoboken, NJ: John Wiley \& Son, Inc.

[38] Roderique, T. W., Polloway, E. A., Cumblad, C., \& Bursuck, W. D. (1994). Homework: A survey of policies in the United States. Journal of Learning Disabilities, 27, 481-487. 
[39] Rothstein, R. (2004). Class and school: Using social, economic and educational reform to close the black-white achievement gap. New York: Teachers College Press.

[40] Savage, T. V., Savage, M. K., \& Armstrong, D. G. (2006). Teaching in the Secondary School. Upper Saddle River, NJ: Pearson-Merrill Prentice Hall.

[41] Solomon, Y., Warin, J., \& Lewis, C. (2002). Helping with homework? Homework as a site of tension for parents and teenagers. British Educational Research Journal, 28(4), 603-622.

[42] Stacey, K. (2003). The need to increase attention to mathematical reasoning. In H. Hollingsworth, J. Lokan, \& B. McCrae, Teaching Mathematic in Australia: Results from the TIMSS 1999 video study (pp. 119-122). Melbourne: Austr4alian Council for Educational Research.

[43] Trautwein, U., \& Koller, O. (2003). The relationship between homework and achievement---still much of a mystery. Educational Psychological Review, 15(2), 115-145.

[44] Trautwein, U., Koller, O., Schmitz, B., \& Baumert, B. (2002).
Do homework assignments enhance achievement? A multilevel analysis in 7th grade mathematics. Contemporary Educational Psychology, 27, 26-50.

[45] Trautwein, U., Schnyder, I., Niggli, A., Neumann, M., \& Lüdtke, O. (2009). Chameleon effects in homework research: The homework-achievement association depends on the measures used and the level of analysis chosen. Contemporary Educational Psychology, 34(2009), 77-88.

[46] Van Voorhis, F. (2003). Interactive homework middle school: Effects on family involvement and Journal of Educational Research, 96, 323-338.

[47] Vaughn, S., Schumm, J. S., \& Sinagub, J. (1996). Focus group interview in education and psychology. Thousand Oaks, CA: Sage.

[48] Vatterott, C. (2009). Rethinking homework: Best practices that support diverse needs. Alexandria, VA: ASCD publications.

[49] Warton, P. M. (2001). The forgotten voice in homework: Views of students. EducationalPsychologists, 36, 155-165 